\title{
運動中のレモン飲料摂取が自律神経活動動態に及ぼす影響
}

\author{
三宅義明
}

(東海学園大学スポーツ健康科学部)

(平成25年 3 月 29 日受付, 平成25年 9 月 30 日受理)

\section{Influence of lemon drink intake during exercise on autonomic nervous system activity}

\author{
Yoshiaki Miyake \\ School of Sport and Health Science, Tokai Gakuen University, \\ 21-233, Nishinohora, Ukigai-cho, Miyoshi-shi, Aichi, 470-0207 \\ 干470-0207 愛知県みよし市福谷町西ノ洞21-233
}

\begin{abstract}
This study examined the influence of lemon drink intake during exercise on the autonomic nervous system activity. Four test drinks (500 $\mathrm{g}$ each) of lemon water, lemon fruit water, honey lemon water, and honey lemon fruit water were prepared. The lemon water and lemon fruit water were prepared by the addition of lemon juice $(40 \mathrm{~g})$ and lemon fruit powder $(1 \mathrm{~g})$ to water, respectively. The honey lemon water and honey lemon fruit water were prepared by the addition of honey $(4 \mathrm{~g})$ to the above lemon drinks. Six healthy male subjects (average age, 21.3 years) exercised using an exercise bike for $20 \mathrm{~min}$ at the heart rate from 110 to $120 \mathrm{bpm}$. They freely ingested all the test drink during the exercise. The autonomic nervous system activity was examined by measuring the variation in the fingertip heart rate before exercise, after exercise, and after a 30-min. rest. For the intake of the honey lemon water, the LF/HF level (sympathetic nerve activity) after exercise was shown to significantly increase in comparison to that before exercise $(p<0.05)$. For the intake of the lemon fruit water, the HF level (parasympathetic nerve activity) after rest was shown to have a tendency to significantly increase in comparison to that before and after exercise $(p<0.1)$. Based on these results, it was suggested that the intake of the honey lemon water during exercise increased the sympathetic nerve activity after exercise and that of the lemon fruit water has a tendency to increase the parasympathetic nerve activity after exercise rest.
\end{abstract}

\section{1. 緒言}

国民の生活の質を向上するには国民の健康維持，健康 増進が重要であり, 厚生労働省は「健康日本21（第二 次) 」1)で国民の健康増進には, 栄養・食生活, 身体活動・ 運動，休養，飲酒，契煙および歯・口腔の健康に関する 生活習慣の改善が重要としている。また,「健康づくり のための身体活動基準2013」2)により身体活動・運動の 重要性の普及啓発が推進されている。栄養・食生活と身 体活動・運動に関する健康増進の観点から, 食生活学分 野では運動における食品のヒトへの影響を検討すること
も必要と考えられる。

体内の血液循環，体温などを調節している自律神経は 交感神経と副交感神経からなり，例えば交感神経は心拍 数，血圧を上昇させて人間が活動するために必要な身体 条件をつくり，副交感神経は心拍数，血圧を下げて休息

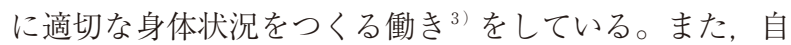
律神経活動はヒトの健康状態にも影響している。一方, 自律神経の交感神経活動と副交感神経活動は, 運動負荷 により変動し，これらのバランスが運動パフォーマンス や疲労などに影響 ${ }^{4}$ を与えると考えられている。 かんきつ果実のレモンはこれまで運動時や運動後など 
に飲食されており, 果糖やブドウ糖などの糖質, クエン 酸などの有機酸，アスコルビン酸などのビタミン，リモ ネンなどの香気成分，フラボノイドなどといった栄養成 分や機能性成分を含んでいる ${ }^{5-7)}$ 。運動後のレモン果汁 の摂取は，血中乳酸濃度の減少を促進する作用 ${ }^{8)}$ が報告 されている。また，安静状態でのレモン摂取による自律 神経活動の変動も報告 $\left.{ }^{9}\right)$ されている。そこで, 本研究で は，運動中にレモン飲料を摂取することによる自律神経 活動の動態に及ぼす影響を調べるため，運動前，運動後， 休㮩後の自律神経活動の変動を測定して検討した。

\section{2. 方 法}

\section{（1）実験材料}

レモン果実（チリ産），水（エビアン，伊藤園・伊藤 忠ミネラルウォーターズ(株)，はちみつ（水谷養蜂(株) は スーパーマーケットにて購入した。レモン果汁は搾汁器 を用いて手絞りして得た。レモン果実 3 個（431 g）を 輪切りにして凍結後に凍結乾燥機にて乾燥物（60 g ）を 得て，これをミルサーにて粉砕してレモン果実粉末を調 製した。試験飲料は, レモン水（レモン果汁 $40 \mathrm{~g}$, 水 $460 \mathrm{~g}$ ), レモン果実水（レモン果実粉末 $1 \mathrm{~g}$, 水 $499 \mathrm{~g}$ ) はちみつレモン水（レモン果汁 $40 \mathrm{~g}$ ， はちみつ $4 \mathrm{~g}$, 水 $456 \mathrm{~g}$ )，はちみつレモン果実水（レモン果実粉末 $1 \mathrm{~g}$, はちみつ $4 \mathrm{~g}$, 水 $495 \mathrm{~g}$ ）の各500 g の 4 試料を調製した。 実験対象者は運動中に飲料を摂取するため，利便性から $500 \mathrm{~mL}$ 容量のペットボトルに試験飲料を入れた。各飲 料の温度は室温とした。

ヘスペリジンと他試薬は和光純薬(株)より購入した。

\section{（2）運動負荷試験}

継続してスポーツ活動をしている健康な大学生男性 6 名（年齢 $21.3 \pm 0.8$ 歳，身長 $171.2 \pm 3.6 \mathrm{~cm}$, 体重 66.2 $\pm 7.4 \mathrm{~kg}$ ）を実験対象者とした。実験内容は東海学園大 学研究倫理委員会にて承認を得て, 実験対象者にイン フォームドコンセントを得た後に実験を実施した。対象 者は実験開始の 2 時間前から飲食を止め，午前10時に実 験を開始した。対象者は自転車エルゴメーター（エアロ バイク $75 \mathrm{XL}$ III，コンビウェルネス(株) で，心拍数110 〜120拍 / 分の範囲内の運動を20分間行った。心拍数と 運動強度換算 (カルボーネン法 $)^{10)}$ により運動強度56 $61 \%$, 主観的運動強度 (RPE: Rating of Perceived Exertion) ${ }^{11)}$ で12,「やや楽」の中程度の運動強度であった。対象者は, 運動中に自ら各試験飲料を摂取したい時に自由に経口捸 取し，運動終了時に飲料の全量を完全に飲み終えた。

\section{（3）自律神経活動測定}

運動負荷した実験対象者の自律神経活動動態を心拍変 動の測定 ${ }^{12-14}$ ) から評価した。すなわち, 運動前, 運動後 (自 転車エルゴメーターのクールダウン後)，30分間の休憩 後に対象者の指尖抹消血管脈拍を加速度脈波測定機（パ
ルスプラスアナライザーTAS 9，(株) YKC）にて 2 分30 秒間測定した。心拍変動の時間領域分析により心拍数 (HR：Heart Rate)，心拍 1 拍ずつの時間の違いである心 拍変動標準偏差（SDNN：Standard Deviation of The NN （RR）Interval）を測定し，周波数領域分析により総自律 神経活動（TP:Total Power），超低周波数成分（VLF：Very Low Frequency)，低周波数成分（LF：Low Frequency）, 高周波数成分 (HF : High Frequency, 副交感神経活動 指標）を測定し, LF/HF 比（交感神経活動指標）を求 めた。TP, VLF, LF, HF, LF/HF の各実験データは Ln 值で示した。

\section{（4）ヘスペリジンの定量}

レモン果汁とレモン果実粉末に含まれるへスペリジン は既報 ${ }^{15,16)}$ に従い高速液体クロマトグラフィー（HPLC） を用いて定量した。果汁は遠心分離機（20,627 × g, 5 分間）にて上清を得て分析試料とした。果実粉末 $0.1 \mathrm{~g}$ に $5 \mathrm{~mL}$ の AWA水溶液(アセトン:水:酢酸 = 70:29.5:0.5) を加え, 1 時間超音波処理して抽出し, 遠心分離処理に て上清を得て分析試料とした。HPLC 分析は, YMCODS カラム (YMC-pack $\phi 4.6 \times 150 \mathrm{~mm}, \mathrm{~S}-5 \mu \mathrm{m})$, $\mathrm{UV}$ 検出器 $280 \mathrm{~nm}$, 移動相はメタノールと $5 \%$ 酢酸水溶 液, 流速 $1 \mathrm{~mL} /$ 分, カラム温度 $40^{\circ} \mathrm{C}$ で行った。移動相 のメタノール濃度を，0-15分は15\%，10-30分は15\%か ら40\%へ，30-40分は40\%から100\%へ濃度勾配変化した。 ヘスペリジンは溶出時間27.3分にピークが検出された。

\section{(5) 統計処理}

各実験群の運動前, 運動後, 休咊後の実験データは, エクセル統計2010（(株)社会情報サービス）の統計ソフト を用い，一元配置分散分析を行い，Fisherの最小有意差 法（PLSD）にて有意差検定を行った。危険率５％（ $p<$ 0. 05）未満を有意差有りとし, 危険率 $5 \%$ 以上 $10 \%$ 未満

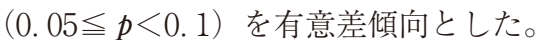

\section{3. 結果および考察}

\section{（1）レモン飲料摂取による自律神経活動の変動}

レモン飲料の作製に関して，容量は運動強度（56〜 $61 \%$ ）と運動時間（20分間）から運動中に摂取量が推 奨 ${ }^{17)}$ されている500 mL（500 g) とした。また，各種レ モン飲料の配合は，運動時飲料として糖質が $8 \%$ 以下と なる水分補給優先型の飲料 ${ }^{17)}$ を調製した。既報では，安 静時でのレモン果汁の単回摂取による脳波測定 ${ }^{18)}$ や自律 神経活動測定 ${ }^{9)}$ でレモン果汁を $30 \mathrm{~g}$ 摂取している。本 試験は運動中20分間内の複数回摂取であることからレモ ン果汁を $40 \mathrm{~g}$ に増量した。かんきつ類に含まれるフラ ボノイドのヘスペリジンを原料として調製される食品素 材の糖転移へスペリジン（ $a$-グルコシルヘスペリジン） には自律神経活動への影響に関する報告 ${ }^{19)}$ がある。本試 験で使用した果汁と果実粉末に含まれるへスペリジンを 
定量したところ, $4.3 \mathrm{mg} / 100 \mathrm{~g}$ 果汁, $1.6 \mathrm{~g} / 100 \mathrm{~g}$ 果実 粉末であった。試験飲料に用いるレモン果汁 $40 \mathrm{~g}$ に含 まれるへスペリジンは $1.7 \mathrm{mg}$ である。レモン果実粉末 の摂取試験は, ヘスペリジンの影響も検討したいため, レモン果汁のヘスペリジンより約10倍増加させてレモン 果実粉末を $1 \mathrm{~g}$ （ヘスペリジン $16 \mathrm{mg}$ 含有）とした。こ のようにして，レモン水はレモン果汁 $(40 \mathrm{~g})$ を，レモ ン果実水はレモン果実粉末 $(1 \mathrm{~g})$ を水に添加して全重 量500 g に調製した。また, レモンの酸味を和らげると ともにエネルギー源でもある糖類のはちみつ20) $(4 \mathrm{~g})$ を両飲料に添加して，はちみつレモン水とはちみつレモ ン果実水も作製した。また, 各試験飲料は, 運動時の飲 料として喏好性が良好であることを事前の官能試験で確 認した。

日本食品標準成分表 ${ }^{21)}$ のレモン果汁，レモン全果（湿 重量当たりのため乾重量当たりに換算)，はちみつの炭 水化物量から総食物繊維量を差し引きして糖質量（g/ $100 \mathrm{~g}$ 食品) を求め, 各試験飲料の糖質含有率を推定した。 レモン水は $0.69 \%$ (3. $44 \mathrm{~g} / 500 \mathrm{~g}$ 飲料), はちみつレモ ン水は $1.33 \%(6.63 \mathrm{~g} / 500 \mathrm{~g}$ 飲料)，レモン果実水は $0.11 \%(0.55 \mathrm{~g} / 500 \mathrm{~g}$ 飲料)，はちみつレモン果実水は $0.75 \%(3.73 \mathrm{~g} / 500 \mathrm{~g}$ 飲料) となり, 試験飲料はすべて 水分補給優先型であった。

運動時にレモン水, レモン果実水, はちみつレモン水, はちみつレモン果実水の試験飲料を摂取した場合の自律 神経活動の変動に関して, 運動前, 運動後, 休㮩後の実 験対象者の心拍数 $(\mathrm{HR})$, 心拍変動標準偏差 $(\mathrm{SDNN})$, 総自律神経活動 (TP), 超低周波数成分 (VLF), 低周 波数成分 ( $\mathrm{LF})$, 高周波数成分 (HF, 副交感神経活動 指標）を測定し，交感神経活動指標（LF/HF）を求め た結果を表 1 に示した。

各実験群の心拍数 (HR) は, 各飲料摂取群で運動前

表 1 運動中のレモン飲料摂取により, 運動前, 運動後, 休噁後の心拍変動から求められる自律神経活動の動態値

\begin{tabular}{|c|c|c|c|c|}
\hline 測定項目 & 実験群 & 運動前 & 運動後 & 休憩後 \\
\hline 心拍数 & レモン水摂取群 & $64.2 \pm 8.7$ & $75.3 \pm 14.4$ & $70.7 \pm 13.7$ \\
\hline \multirow[t]{3}{*}{ HR (bpm) } & レモン果実水摂取群* & $68.5 \pm 10.0^{\mathrm{a}}$ & $80.5 \pm 8.1^{b}$ & $67.8 \pm 6.5^{\mathrm{a}}$ \\
\hline & はちみつレモン水摂取群* & $62.3 \pm 7.7^{\mathrm{a}}$ & $77.0 \pm 7.0^{\mathrm{b}}$ & $65.0 \pm 10.3^{\mathrm{a}}$ \\
\hline & はちみつレモン果実水摂取群* & $72.7 \pm 10.3^{\mathrm{a}}$ & $82.7 \pm 11.8^{\mathrm{a}}$ & $68.8 \pm 6.7^{\mathrm{b}}$ \\
\hline 心拍変動標準偏差 & レモン水摂取群 & $73.4 \pm 36.9$ & $54.3 \pm 36.1$ & $70.4 \pm 45.4$ \\
\hline \multirow[t]{3}{*}{$\mathrm{SDNN}(\mathrm{ms})$} & レモン果実水摂取群1) & $62.1 \pm 25.9$ & $50.6 \pm 11.5$ & $92.4 \pm 52.6$ \\
\hline & はちみつレモン水摂取群 & $59.6 \pm 20.8$ & $63.7 \pm 36.5$ & $64.5 \pm 31.0$ \\
\hline & はちみつレモン果実水摂取群 ${ }^{2)}$ & $53.8 \pm 17.1$ & $55.0 \pm 19.9$ & $81.5 \pm 30.3$ \\
\hline 総自律神経活動 & レモン水摂取群 & $7.55 \pm 0.82$ & $7.22 \pm 1.04$ & $7.65 \pm 1.06$ \\
\hline \multirow[t]{3}{*}{ Ln TP $\left(\mathrm{ms}^{2}\right)$} & レモン果実水摂取群 ${ }^{3)}$ & $7.14 \pm 0.52$ & $7.09 \pm 0.50$ & $7.89 \pm 0.88$ \\
\hline & はちみつレモン水摂取群 & $7.39 \pm 0.57$ & $7.27 \pm 0.80$ & $7.63 \pm 0.56$ \\
\hline & はちみつレモン果実水摂取群 & $6.97 \pm 0.40$ & $6.99 \pm 0.97$ & $7.60 \pm 0.69$ \\
\hline 超低周波数成分 & レモン水摂取群 & $6.33 \pm 0.28$ & $6.01 \pm 0.38$ & $6.07 \pm 0.34$ \\
\hline \multirow{3}{*}{$\operatorname{Ln} \operatorname{VLF}\left(\mathrm{ms}^{2}\right)$} & レモン果実水摂取群* & $6.08 \pm 0.29^{\mathrm{ab}}$ & $5.88 \pm 0.18^{a}$ & $6.26 \pm 0.37^{\mathrm{b}}$ \\
\hline & はちみつレモン水摂取群* & $6.31 \pm 0.27^{\mathrm{a}}$ & $5.96 \pm 0.26^{\mathrm{b}}$ & $6.23 \pm 0.30^{\mathrm{ab}}$ \\
\hline & はちみつレモン果実水摂取群 & $6.03 \pm 0.34$ & $5.86 \pm 0.32$ & $6.15 \pm 0.20$ \\
\hline 低周波数成分 & レモン水摂取群 & $6.60 \pm 1.35$ & $6.38 \pm 1.31$ & $6.95 \pm 1.30$ \\
\hline \multirow[t]{3}{*}{$\operatorname{Ln} \operatorname{LF}\left(\mathrm{ms}^{2}\right)$} & レモン果実水摂取群 ${ }^{4)}$ & $5.95 \pm 1.04$ & $6.16 \pm 0.60$ & $6.97 \pm 1.08$ \\
\hline & はちみつレモン水摂取群 & $5.95 \pm 1.13$ & $6.44 \pm 1.00$ & $6.66 \pm 0.69$ \\
\hline & はちみつレモン果実水摂取群 & $5.64 \pm 0.77$ & $5.81 \pm 1.27$ & $6.44 \pm 1.22$ \\
\hline \multirow{4}{*}{$\begin{array}{l}\text { 高周波数成分 } \\
\text { Ln HF }\left(\mathrm{ms}^{2}\right) \\
\text { 副交感神経活動指標 }\end{array}$} & レモン水摂取群 & $5.98 \pm 0.78$ & $5.43 \pm 1.53$ & $5.96 \pm 1.42$ \\
\hline & レモン果実水摂取群 ${ }^{5)}$ & $5.65 \pm 1.01$ & $5.61 \pm 1.00$ & $6.69 \pm 1.03$ \\
\hline & はちみつレモン水摂取群 & $6.27 \pm 0.71$ & $5.77 \pm 1.10$ & $6.49 \pm 0.84$ \\
\hline & はちみつレモン果実水摂取群 & $5.38 \pm 1.13$ & $5.23 \pm 2.05$ & $6.40 \pm 1.14$ \\
\hline \multirow{4}{*}{ 交感神経活動指標 } & レモン水摂取群 & $1.10 \pm 0.13$ & $1.22 \pm 0.23$ & $1.19 \pm 0.14$ \\
\hline & レモン果実水摂取群 & $1.06 \pm 0.11$ & $1.11 \pm 0.11$ & $1.05 \pm 0.12$ \\
\hline & はちみつレモン水摂取群* & $0.95 \pm 0.15^{\mathrm{a}}$ & $1.13 \pm 0.10^{\mathrm{b}}$ & $1.03 \pm 0.09^{\mathrm{ab}}$ \\
\hline & はちみつレモン果実水摂取群 & $1.10 \pm 0.32$ & $1.21 \pm 0.30$ & $1.02 \pm 0.19$ \\
\hline
\end{tabular}

\footnotetext{
*アルファベット記号が異なる群間で有意差あり $(p<0.05)$

1) $p=0.053$, 運動後 vs 休息後

2) $p=0.063$, 運動後 vs 休息後, $p=0.056$, 運動前 vs 休憩後

3) $p=0.053$, 運動後 vs 休息後, $p=0.065$, 運動前 vs 休憩後

${ }^{4)} p=0.079$, 運動前 vs 休憩後

${ }^{5} p=0.083$, 運動後 vs 休息後, $p=0.096$, 運動前 vs 休憩後
} 
に比べて運動後に増加し, 休喤にて減少していた。各群 で運動負荷による心拍数の増加と休款による心拍数の減 少が確認できた。各実験群の心拍変動標準偏差 (SDNN) は，休㴧後に上昇の傾向がみられた。レモン果実水摂取 群とはちみつレモン果実水撕取群では, 運動後と比べて 休悡後に上昇の傾向がみられた $(\boldsymbol{p}<0.1)$ 。SDNN 值の 低下は身体的ストレス（身体的疲労）との関連 ${ }^{12}$ が示さ れて抢り，運動時のレモン果実水の摂取は，休息時に運 動負荷による身体的疲労を緩和させる作用が示唆された。 レモン果実水の原料であるレモン果実粉末には，レモン 果皮に高含有成分なりモネン，ヘスペリジンが多く含ま れており, これらの影響も推測された。また, 有意差や 有意差傾向は認められなかったが, SDNN 值の運動後 の低下は，レモン水とレモン果実水摂取群にみられ，は ちみつレモン水とはちみつレモン果実水撕取群ではみら れなかった。運動後の身体的疲労は，はちみつ添加の飲 料で低減されたことも推測されたが，運動強度などの条 件からさらに検討する必要がある。

心拍変動の周波数分析から求めた総自律神経活動 （TP）は，各実験群で運動後にほほ同等かやや低下し， 休惒後に増加がみられた。レモン果実水摂取群において 休憩後は運動前と運動後に比べて有意差傾向の上昇がみ られた $(p<0.1)$ 。既報では，運動と自律神経活動動態 の関係については, 運動負荷によって交感神経活動の上 昇と副交感神経活動の低下が，運動後の休息により交感 神経活動の低下と副交感神経活動の上昇が報告 ${ }^{3,222}$ され ている。本実験の各実験群では, 副交感神経活動指標の $\mathrm{HF}$ 值は，運動後に低下して休䡯後に上昇しており，既 報と同様な変動を示した。また、レモン果実水摂取群の 休悡後の $\mathrm{HF}$ 值は, 運動前と運動後に比べて有意差傾向 の上昇がみられた $(p<0.1)$ 。はちみつレモン果実水摂 取群は，レモン果実水摂取群のような有意差傾向はな かったが同様な変動がみられた。レモン果実水摂取の効 果は，前述のSDNN 值と同様にレモン果皮に含まれる 成分の影響が推測され，ヘスペリジン類縁化合物には副 交感神経活動を高めるという報告 ${ }^{19)}$ があり，その影響が 推測された。また, 各実験群の TP 值と HF 值の変動パ ターンは類似し，両者ともにレモン果実水摂取群の休悡 後で上昇の有意差傾向があることから, 副交感神経活動 は総自律神経活動に影響を与えていると考えられた。

本実験の各摂取群の交感神経活動指標（LF/HF）に ついては，運動後に上昇し，休息で低下がみられ，既報 と同様な変動3,22) であった。はちみつレモン水摂取群の 運動後の $\mathrm{LF} / \mathrm{HF}$ 值は, 運動前に比べて有意に上昇して おり $(p<0.05)$ ，運動による交感神経活動の上昇を高め る作用が示された。安静時でのレモン果肉とブドウ糖液 の同時摂取で交感神経活動が方進する報告 ${ }^{9)}$ があり，本 実験では運動中のはちみつレモン水摄取で運動後に同様 な作用が示された。

以上の実験結果から，運動中のレモン飲料の摂取は，
運動後, 休悡後の自律神経活動の動態に影響を与えるこ とが示された。レモン果実水の摂取は，SDNN 值，HF 值の変動から，休憩時に運動による身体的ストレスや身 体的疲労を軽減し, 副交感神経活動の上昇より精神的リ ラックス作用が示唆された。また，はちみつレモン水の 摂取は, LF/HF 值の変動から運動後に交感神経活動を 高める効果がみられ，運動によって高まった緊張や集中 力を維持する作用が示唆された。

本研究の一部は，科学研究費補助金・基盤研究 (C) （No.23500975）の助成を受けて行われた。

\section{（2）まめ}

6 名の健康な男性被験者（平均年齢21.3歳）は, 自転 車エルゴメーターによる20分間の運動中に各種レモン飲 料（レモン水，レモン果実水，はちみつレモン水，はち みつレモン果実水）を摂取し, 運動前, 運動後, 休頽後 の心拍変動を測定することによりレモン飲料が自律神経 活動動態に及ぼす影響を調べた。レモン果実水とはちみ つレモン果実水の摂取では, 心拍変動標準偏差值 （SDNN）が休鄎後に有意差傾向の上昇を示していた（ $p$ $<0.1)$ 。また，レモン果実水摄取は，運動によって低下 する総自律神経活動（TP）と副交感神経活動（HF）が 休鄎後に上昇傾向が示された $(p<0.1)$ 。レモン果実水 は運動休䟤後に SDNN 值, TP 值, HF 值を高める効果 が示唆された。一方，はちみつレモン水摂取では交感神 経活動（LF/HF）が運動後に有意に上昇した $(p<0.05)$ 。 これらの結果から，レモン果実水の摂取は，休䕀時に身 体的ストレスの軽減と副交感神経を高める効果が示唆さ れた。また，はちみつレモン水の摂取は，運動後に交感 神経活動を高める効果が示された。

\section{文献}

1）厚生労働省：国民の健康の増進の総合的な推進を図るた めの基本的な方針. 健康日本 21 (第二次), http://www. mhlw.go.jp/bunya/kenkou/kenkounippon21.html

2 ）厚生労働省健康局がん対策・健康増進課：「健康づくりの ための身体活動基準2013」及び「健康づくりのための身体 活動指針（アクティブガイド）」について, 厚生労働省報道 発表資料，平成25年 3 月 18 日

3 ）大宮一人：運動と自律神経，心臟リハビリテーション， 6 147-149（2001）

4 ）勝村貴行，鳥居俊，内藤健二，石川真理：短期間高強度 の運動負荷による疲労が自律神経系活動に与える影響，体 力科學， $51 ， 81(2002)$

5 ）川本利恵子, 村瀬千春, 石原逸子, 生嶋美春, 中谷淳子 原賀美紀，清水遵：レモンの香りが単純精神作業㧍よび心 身に拈よぼす効果，産業医科大学雑誌，27，305-313（2005）

6 ）三宅義明：レモンポリフェノールの効果，バイオサイエ ンスとインダストリー，64，20-22（2006）

7 ) 高寺恒慈，柴田重信：リモネンおよびレモン果汁の体内 時計遺伝子調節作用, Aroma Res., 12, 333 (2011) 
8）三宅義明, 山本兼史, 長崎大, 中井直也, 村上太郎, 下 村吉治：ヒトに扔けるレモン果汁㧍よびクエン酸揁取が運 動後の血中乳酸濃度に及ぼす影響, 日本栄養・食糧学会誌, 54, 29-33 (2001)

9）永井成美, 坂根直樹, 森谷敏夫：レモン, グレープフルー ツ摂取が自律神経活動動態に及ぼす効果, 日本肥満学会誌, 14, $7-24$ (2008)

10）正保哲, 洲崎俊男, 立野勝彦, 出口清喜, 廣瀬昇, 奥壽郎 : Karvonen 法による運動負荷強度における生体反応, 理学療 法科学, 26, 33-39 (2011)

11）北村潔和：ランニングとウォーキングの主観的運動強度 と心拍数, 臨床スポーツ医学, 13，459-463（1996）

12) Guideline: Heart rate variability. Standards of measurement, physiological interpretation, and clinical use. Task Force of the European Society of Cardiology and the North American Society of Pacing and Electrophysiology., Eur. Heart. J., 17, 354-381（1996）

13）五島史行, 水足邦雄, 國弘幸伸, 小川郁: 指尖脈波解析 を用いためまい患者の自律神経機能評価, Equilib. Res., 69, 207-212 (2010)

14）井川純一, 中西大輔, 車地未帆, 菊本修, 井手下久：心 拍変動を用いた不安の自律神経機能評価について, バイオ フィードバック研究，37，97-103（2010）
15) Miyake, Y., Yamamoto, K., Morimitsu, Y., Osawa, T.: Characteristics of antioxidative flavonoid glycoside in lemon fruit., Food Sci. Technol. Int. Tokyo, 4 , 48-53 (1998)

16）三宅義明, 井藤千裕, 糸魚川政孝：マイヤーレモンに含 まれるフラボノイド, クマリンの特徴, 日本食品科学工学 会誌, 58, 178-181 (2011)

17）樋口満：新版コンディショニングのスポーツ栄養学, 市 村出版, p.114-125（2007）

18）石川清香, 三宅義明, 横越英彦：レモン果汁の香り成分に よるラットの脳内神経伝達物質及びヒトの脳波に与える影 響について, Aroma Res., 3, 126-130（2002）

19) Takumi H, Fujishima N, Shiraishi K, Mori Y, Ariyama A, Kometani T, Hashimoto S, Nadamoto T.: Effects of alphaglucosylhesperidin on the peripheral body temperature and autonomic nervous system. Biosci. Biotechnol. Biochem., 74, 707-715 (2010)

20) Bogdanov, S., Jurendic, T., Sieber, R., Gallmann, P.: Honey for Nutrition and Health: A Review. J. Am. Coll. Nutr., 27, 677 -689 (2008)

21）香川芳子監修: 五訂増補食品成分表2011, 女子栄養大学 出版部（2010年）

22）松川寛二：運動と心臓・血管 運動と心拍動リズムの自律 神経調節，体育の科学，62，252-259（2012） 